\title{
ROTUNDA NA KOPCU KRAKUSA?
}

\section{ROTUNDA ON THE KRAKUS MOUND?}

\author{
Leszek P. Stupecki \\ https://orcid.org/0000-0002-2634-4026 \\ Instytut Historii Uniwersytetu Rzeszowskiego \\ Aleje T. Rejtana 16 C, 35-959 Rzeszów \\ leszek.slupecki@interia.pl
}

\begin{abstract}
The paper focuses on the question of a mysterious building on the top of Krakus burial mound (Cracow, Poland) which was documented on some engravings from the late 16th and 17th century presenting panoramas of the city of Cracow (Matthäus Merian, 1617; and Eric Dahlberg, 1655). On the Swedish map from 1702 the top of the mound is already empty. The hypothesis is that probably a small Romanesque rotunda stood there. The facility established over a big burial mound resembles the case of St. Nicholas (Sv. Nikola) church in Nin (Croatia) which is an early Romanesque rotunda (triconchos) from ca. $1100 \mathrm{AD}$ which stands till today on the top of a prehistoric mound. In Cracow excavation done on Krakus mound in 30ties eventually revealed a negative of destroyed foundations od the rotunda, which remained uninterpreted.
\end{abstract}

KEY WORDS: Cracow, Krakus mound, great burial mounds, Vistulanians, Romanesque rotonda, engravings, Matthäus Merian the Younger, Eric Dahlbergh, Nin, triconchos, Sv. Nikola's chuch

Temat rotund i podobnych do nich małych sakralnych budowli romańskich i przedromańskich, takich jak badany przez Profesora Stanisława Tabaczyńskiego zawichojski „tetrakonchos” (Tabaczyński, Wyczółkowski, Cyngot, 2018), to wdzięczny temat do badań nie tylko dla archeologów i architektów, ale także historyków, historyków sztuki, a nawet badaczy ikonografii i dawnej kartografii.

W czasach, gdy Profesor Stanisław Tabaczyński badał Zawichost, dawna kartografia zaprowadziła mnie pod Wawel, a przedmiotem moich zainteresowań stały się kopce Wandy i Krakusa, przede wszystkim jednak związane z tym ostatnim duże skupisko kopców i kurhanów na krakowskich Krzemionkach, widoczne dziś już tylko na archiwalnych mapach i planach (Słupecki, 1998). W latach dziewięćdziesiątych ubiegłego stulecia udało mi się odkryć w Archiwum Wojennym w Sztokholmie na szwedzkim planie z 1702 
roku (oraz na jego szkicu roboczym) kilka wielkich mogił (było ich cztery lub pięć), tworzących odrębną grupę wielkich mogił wznoszących się w pobliżu Kopca Krakusa ${ }^{1}$.

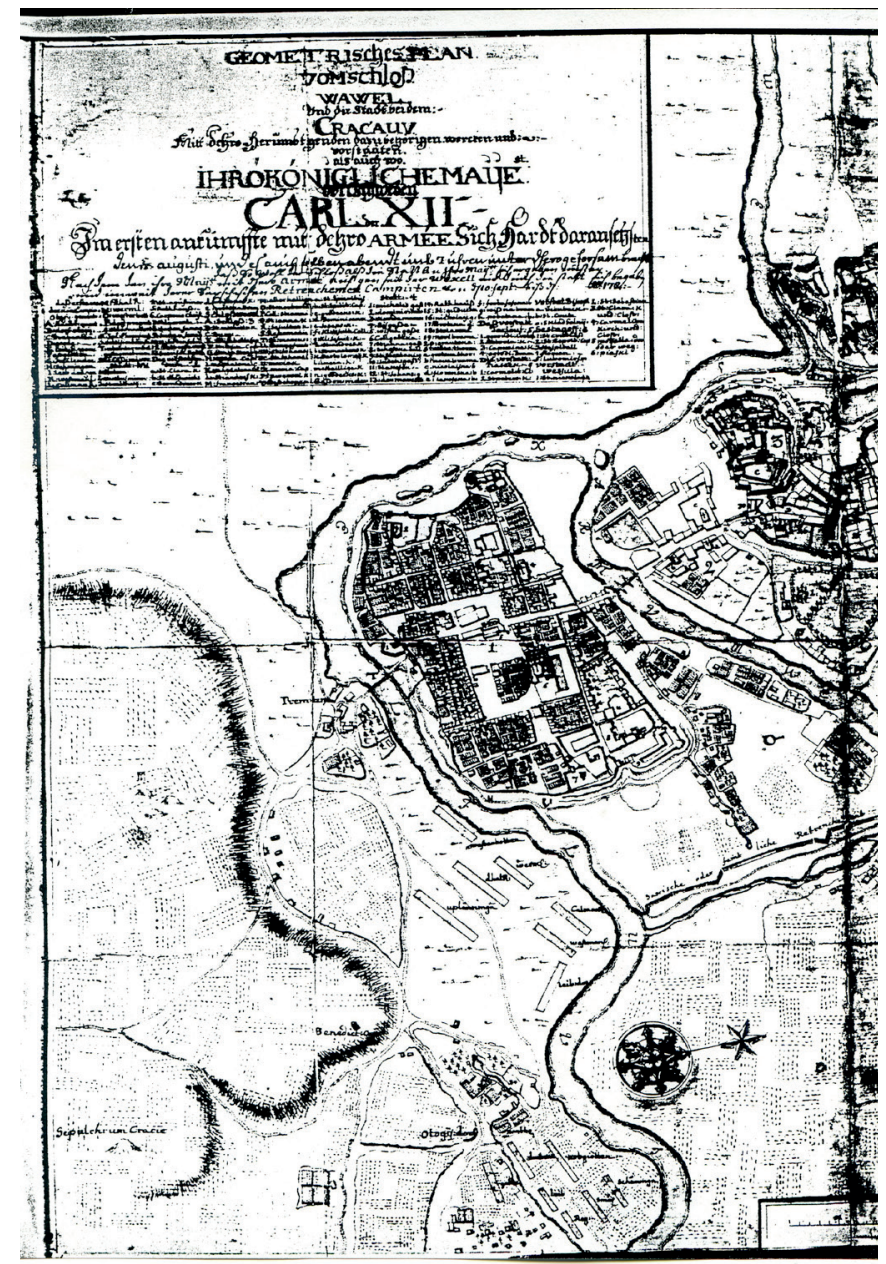

Ryc. 1. Fragment szwedzkiego planu Krakowa z 1702 roku wykonany podczas oblężenia miasta przez Szwedów, przedstawiający Kopiec Krakusa (Sepulchrum Cracie), kościółek św. Benedykta (Benedict[us] i, powyżej nich, kilka dużych kopców oraz szubienicę (Stockholm, Krigsarkivet: Sveriges krig 10: 182a)

Fig. 1. Fragment of the Swedish plan of Krakow from 1702 during the siege of the city by the Swedes, showing the Krakus Mound (Sepulchrum Cracie), the church of St. Benedict (Benedict[us]) and above them several large mounds and a gallows (Stockholm, Krigsarkivet: Sveriges krig 10: 182a)

${ }^{1} \mathrm{Na}$ szkicu roboczym w pobliżu Kopca Krakusa oznaczono tylko jedną z nich, być może największą, i szubienicę, zob. Geometrisches Plan vom Schloß Wawel (Stockholm, Krigsarkivet: Sveriges krig 10, 182a „mapa“ i 182b „szkic“). Mapa przedstawia Kraków z okolicami podczas oblężenia miasta przez Szwedów w 1702 roku. Była łatwo dostępna dla polskich historyków, ponieważ w początkach XX w. przedrukowano ją w Galicji, tyle że nikt nie zwrócił uwagi na to, że poza Kopcem Krakusa w jego pobliżu widnieją na niej inne jeszcze duże mogiły! (patrz: Słupecki, 1998, s. 58). 


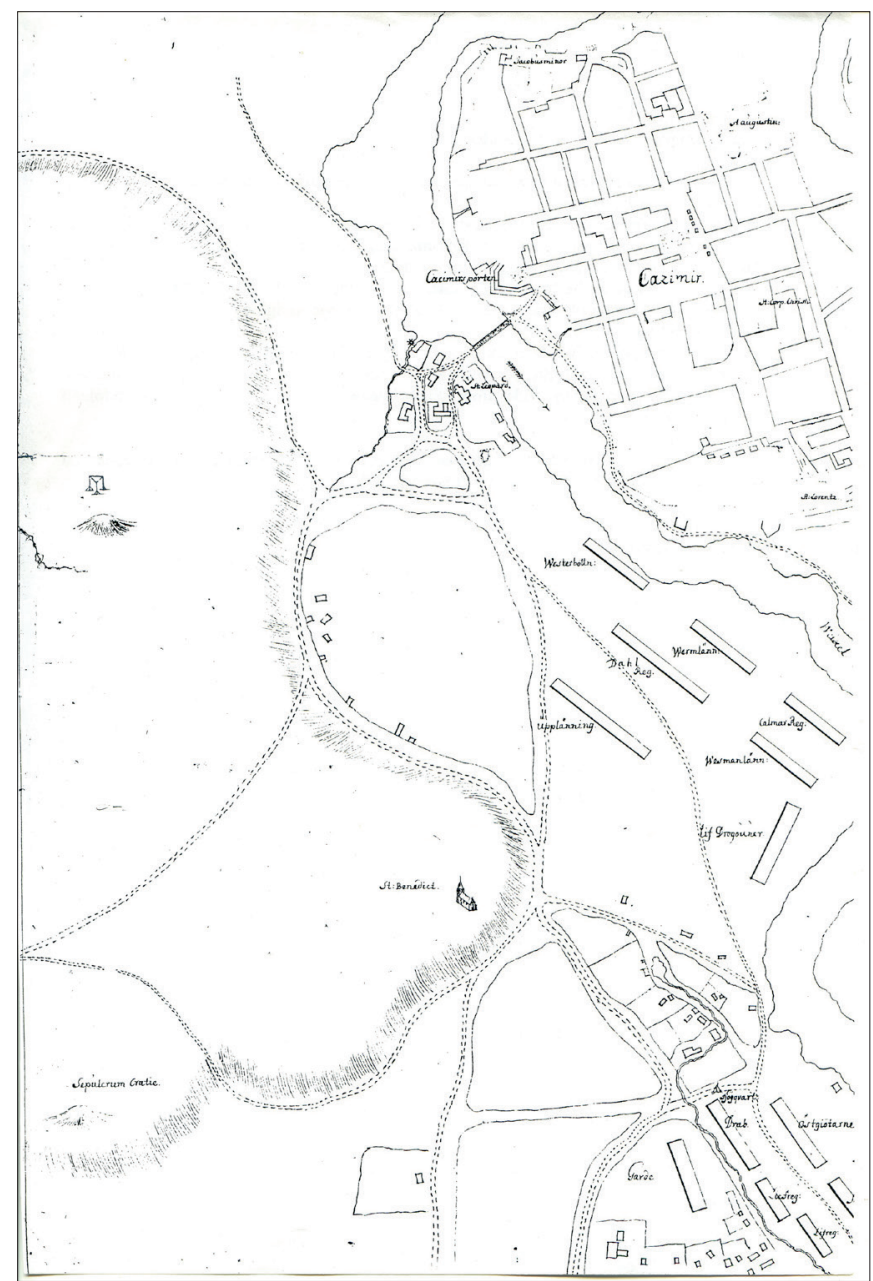

Ryc. 2. Szkic roboczy szwedzkiego planu Krakowa z 1702 roku. Ponad Kopcem Krakusa (Sepulcrum Cratie) i kościółkiem św. Benedykta (St Benedict) przedstawiony JEDEN wielki kopiec i ZA NIM szubienica (Stockholm, Krigsarkivet: Sveriges krig 10: 182b)

Fig. 2. Sketch of the Swedish plan from 1702. Above the Krakus Mound (Sepulcrum Cratie) and the Church of St. Benedict (St. Benedict) Depicted ONE great mound and the gallows BEHIND HIM (Stockholm, Krigsarkivet: Sveriges krig 10: 182b)

Należy do nich dodać jeszcze kilkanaście mniejszych kurhanów, towarzyszących i im, i Krakusowi, a widocznych na późniejszych planach austriackich z końca XVIII w. i na rycinach z XIX w. ${ }^{2}$

${ }^{2}$ Austriacka mapa z 1779 roku znana była Rudolfowi Jamce (Jamka, 1965, s. 188). Z jego przedruku mapy skorzystałem w 1998 roku (Słupecki, 1998, s. 71). Do oryginału tej mapy (i jeszcze kilku późniejszych) dotarł Kazimierz Radwański (Radwański, 2000a, s. 275), który doliczył się na tych mapach 


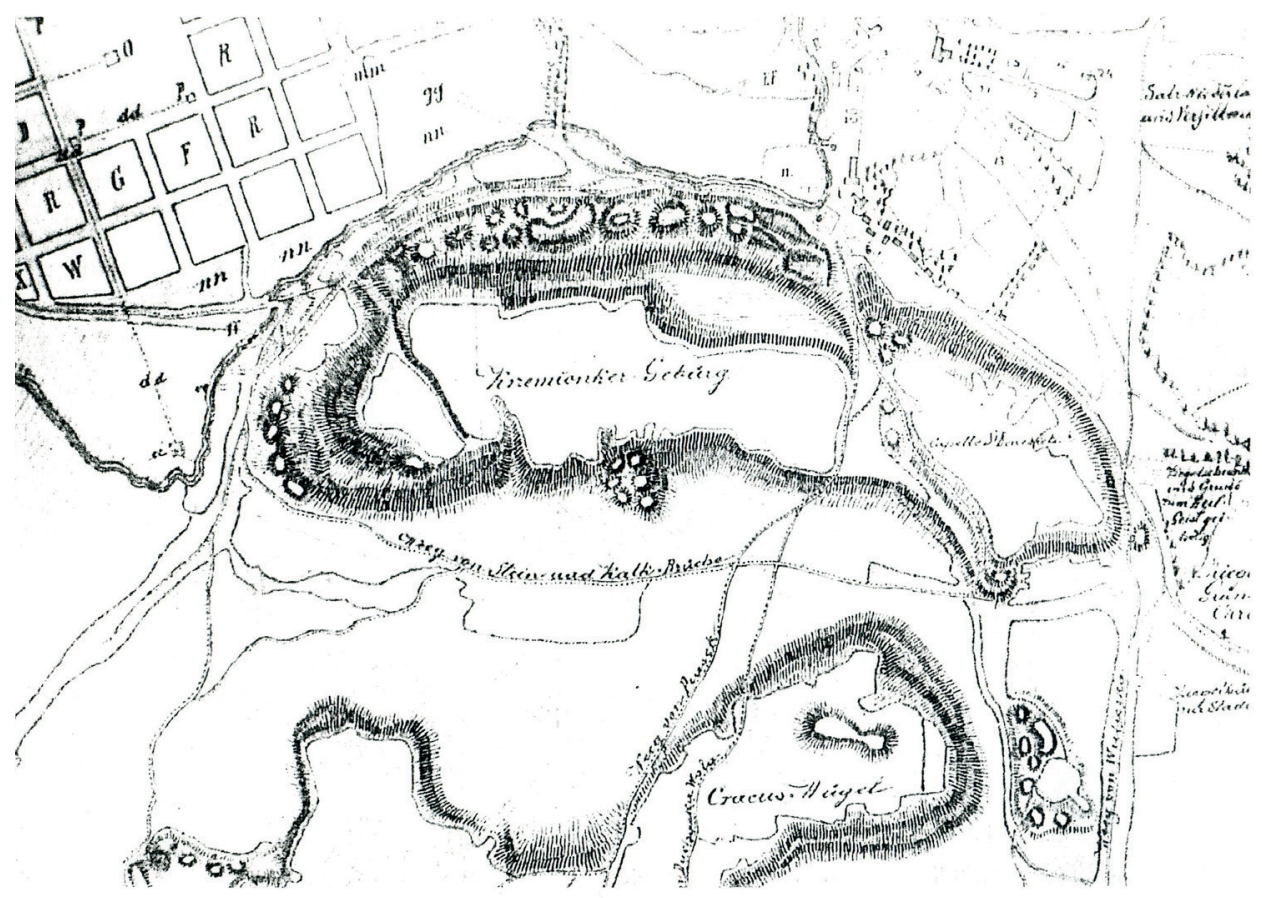

Ryc. 3. Austriacki plan krakowskich Krzemionek Charlesa de Hoeferna z 1779 roku, skala ok. 1 : 7500 , według dziewiętnastowiecznej kopii przechowywanej w Muzeum Historycznym Miasta Krakowa, sygn. 24/VIIIa (za: Radwański, 2000, s. 544)

Fig. 3. Austrian plan by Charles de Hoefern from 1779, scale approx. 1: 7,500, 19th-century copy of the plan kept in the Historical Museum of the City of Kraków, ref. 24 / VIIIa (after: Radwański, 2000, p. 544)

Po tych badaniach okazało się, że Kopiec Krakusa jest jedynie ostatnim śladem istnienia w Krakowie dużego cmentarzyska kurhanowego, porównywalnego - zachowując należne proporcje - do tych w Starej Uppsali, Jelling, Czernihowie i w wielu innych miejscach świata, głównie wszakże - choć nie wyłącznie - skandynawskiego (Słupecki, 1999, 2002, 2004, 2006).

Takie zgrupowania wielkich, monumentalnych mogił są mocnym świadectwem istnienia $\mathrm{w}$ ich pobliżu ważnych ośrodków protopaństwowej władzy. Wiązane są - całkiem słusznie - z budującymi je elitami i królewskimi dynastiami, legitymizującymi

istnienia na Krzemionkach co najmniej 48 kopców i kurhanów i próbował je w swoich studiach, z pewnym powodzeniem, zlokalizować. Niestety niewiele nowego do kartograficznego dossier nie wnosi słynna Mapa Miega (topograficzna mapa Galicji 1779-1783, zob. Galicja na józefińskiej mapie... 2012, t. 1, cz. A, s. 161; cz. B, sekcja 23), choć zaznacza Kopiec Krakusa wraz z jego nazwą zapisaną jako „Krakus" potraktowaną w opisie jako nazwa wzgórza. Niewielkie nadzieje na dokładną identyfikację miejsc, w których znajdowały się widoczne na planach i mapach kopce, daje ewentualnie skanowanie lidarowe; niestety w przekształconym bardzo mocno terenie nie można się spodziewać rewelacyjnych wyników. 


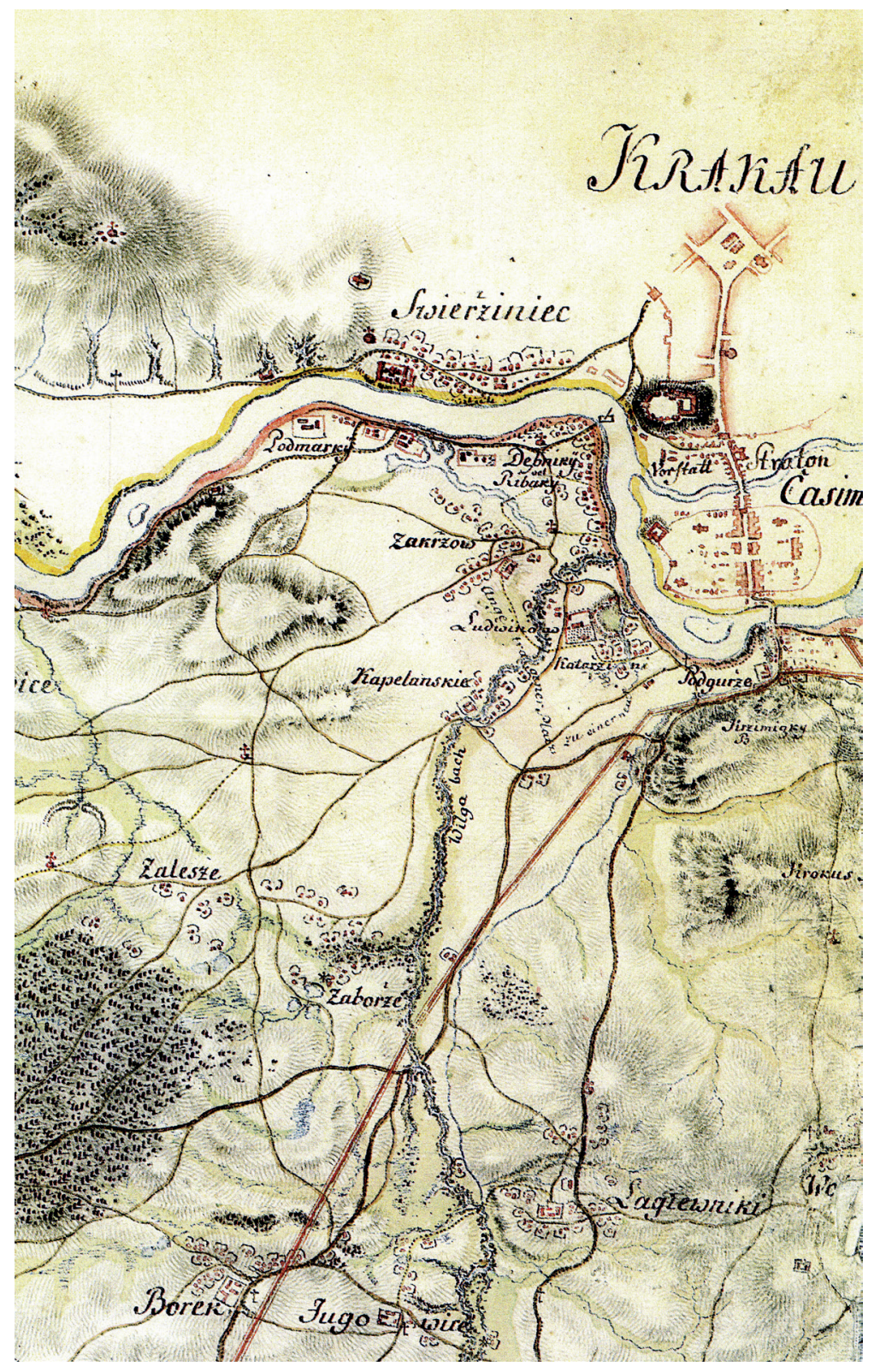

Ryc. 4. Fragment Mapy Miega. Od góry widoczny Kraków (Krakau), poniżej jego dzielnice Podgórze (Podgurze), Krzemionki (Krzemiąky) oraz Kopiec Krakusa (Krokus) (za: Galicja na józefińskiej mapie... 2012, t. 1, cz. B, sekcja 23, 1-2D)

Fig. 4. A fragment of Mieg's map. Visible from above is Cracow (Krakau), below its districts Podgórze (Podgurze), Krzemionki (Krzemiąky) and Krakus Mound (Krokus) (after: Galicja na józefińskiej mapie... 2012, vol. 1, part B, section 23, 1-2D) 


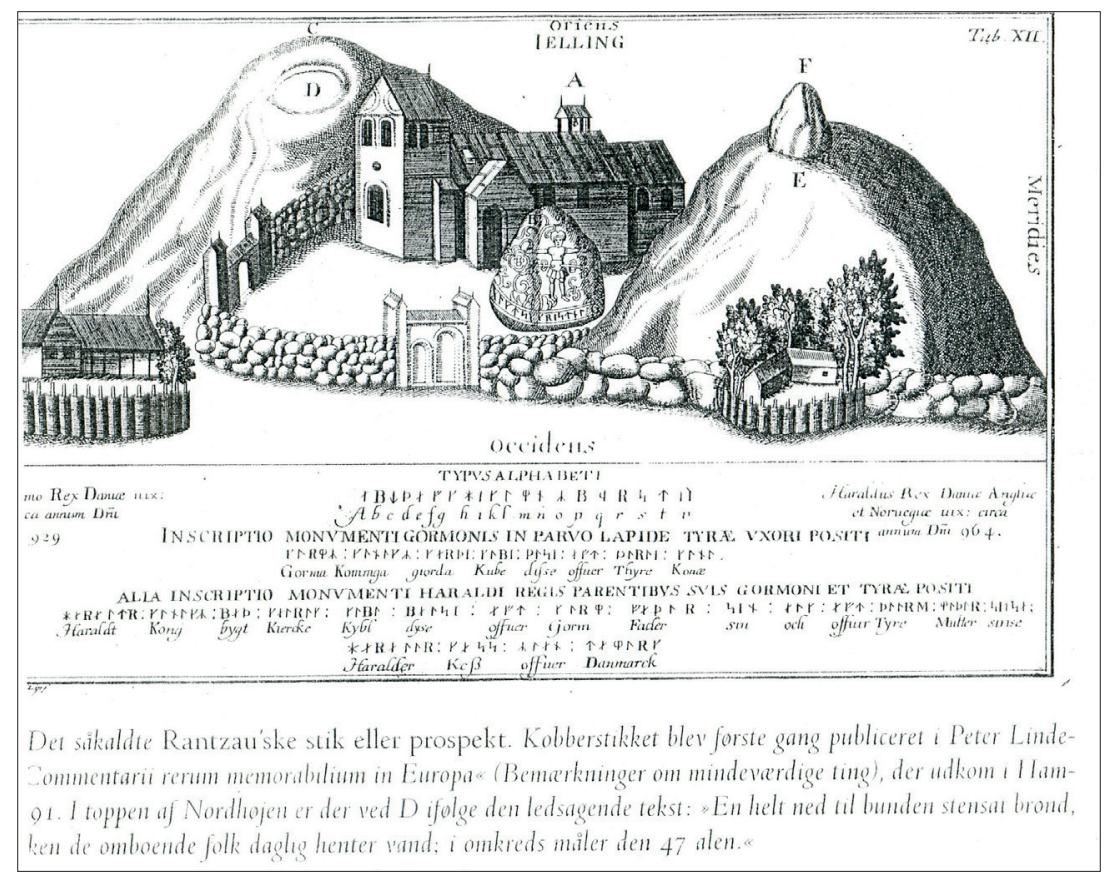

Ryc. 5. Jelling. Miedzioryt Heinricha Rantzaua z 1591 roku przedstawiający kościół w Jelling, dwa wielkie kopce i kamień runiczny króla Gorma (opublikowany w: Petrus Lindeberg, Commentarii Rerum Memorabilium in Europa Ab Anno Octuagesimo sexto usque ad presentem...; wyd. Wolfius, Hamburgii, 1591, s. 98-99)

Fig. 5. Jelling. Copperplate engraving by Heinrich Rantzau from 1591 depicting the church in Jelling, two great mounds and King Gorm's runestone (published in: Petrus Lindeberg, Commentarii Rerum Memorabilium in Europa Ab Anno Octuagesimo sexto usque ad presentem...; Wolfius (ed.), Hamburg, 1591, p. 98-99).

swoje prawa do rządów przez odwoływanie się do pochowanych na takich cmentarzyskach przodków: tych prawdziwych i faktycznie w owych sporym nakładem sił wznoszonych i wyposażanych mogiłach pochowanych oraz tych mitycznych, legendarnych, a czasami wręcz propagandowo urojonych. Takie związki ważnych mogił z dynastią mogły więc być tworzone na aktualne potrzeby przez ich zbudowanie i dokonywane w nich pochówki, ale także kreowane dla różnych potrzeb kilka wieków po ich usypaniu. Często dopiero w późnym średniowieczu osobom jakoby w takich mogiłach pochowanym nadawano imiona postaci z narodowych legend, czerpiąc je z przetworzonych i po wielokroć przeredagowanych tradycji. Obecne nazwy kopców pojawiają się więc niekiedy dopiero kilka stuleci po całkiem realnych pochówkach, jakich w nich dokonano. Dobrym przykładem są tu kopce Auna, Adilsa i Egila w Starej Uppsali ${ }^{3}$.

${ }^{3}$ Trzy wielkie kopce w Starej Uppsali (dwa z nich przebadano w XIX w.) pochodzą z VI w. Stan badań i nowsze badania w Starej Uppsali przedstawia Władysław Duczko (Duczko, red., 1993, 1996) Po raz pierwszy połączył te trzy wielkie kopce z trzema legendarnymi królami z dynastii Ynglingów: Aunem, Egilem i Adilsem dopiero w XIII w. Snorri Sturluson (Heimskringla, Ynglinga saga, cap. 26, 29: Íslenzk 


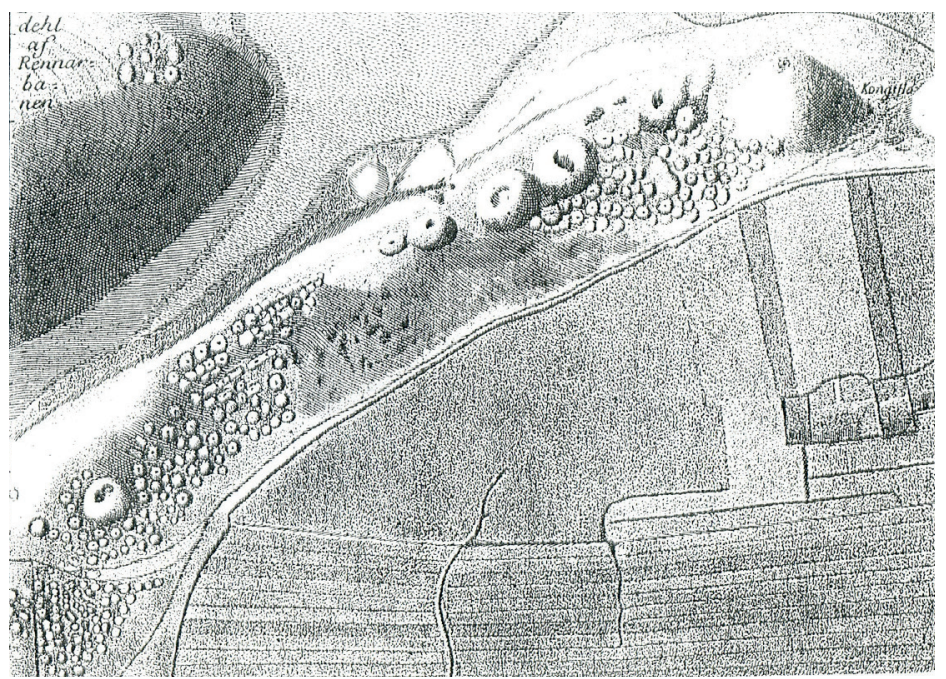

Ryc. 6. Stara Uppsala. Wielkie kopce na planie Johana Peringskjölda. Johan Peringskjöld, Monumenta Uplandica per Thiundiam, Stockholmiae, 1710 (za: Duczko, red., 1993, s. 100)

Fig. 6. Old Uppsala. Huge mounds on the plan of Johan Peringskjöld. Johan Peringskjöld, Monumenta Uplandica per Thiundiam, Stockholmiae, 1710 (after: Duczko, ed., 1993, p. 100)

Jeszcze może lepszym potwierdzeniem takiej praktyki jest Kopiec Wandy pod Krakowem (Słupecki, 2005). W innych jednak miejscach związek wielkich mogił z ich mieszkańcami bywa wszakże autentyczny, oczywisty i dobrze poświadczony od samego początku, tak jak to się dzieje w przypadku sławnych kopców z Jelling na duńskiej Jutlandii, gdzie dwa kamienie runiczne mówią jasno i intencjonalnie, że jest to królewska nekropola konkretnych, podpisanych nieomalże własnoręcznie historycznych władców: na jednym z kamieni runicznych do dziś tam stojących król Gorm wspomina usypanie kopca i pochowanie w nim jego żony, królowej Tyry, a na drugim kamieniu ich syn Harald sinozęby wspomina pochówki swoich rodziców: Gorma i Tyry ${ }^{4}$.

Fórnrit, t. 26, wyd. Bjarni Aðalbjarnarson, Reykjavík, 1939, s. 49, 52, 58) - mimo że nie wspomina o tym wprost jego źródło, cytowany przez niego (i dzięki temu częściowo zachowany) poemat Ynglinga tal skalda Thiodolfa. Niemniej warto pamiętać, że już skald Thiodolf w Ynglinga tal uważał ich wszystkich za królów uppsalskich, a śmierć królów Auna i Adilsa umiejscawiał w Uppsali (Heimskringla, Ynglinga saga, s. 59)! Tak czy inaczej od pochówku do pierwszego poświadczenia imion pochowanych w kopcach królów upłynęło co najmniej kilkaset lat.

${ }^{4}$ Baza danych inskrypcji na kamieniach runicznych - Rundata (https://rundata.info/ [dostęp 16.07.2020]):

Rundata DR 41: kurmR: kunukR: k(ar)pi: kubl: pusi a(ft) purui: kunu: sina; tanmarkaR; but; Rundata DR 42: haraltr: kunukR: bap: karua: kubl: pausi: aft: kurm fapur sin: auk aft: purui: mopur: sina. [DR 41: „Król Gorm wzniósł ten monument ku czci Tyry, swojej żony, ozdoby Danii”; DR 42: „Król Harald nakazał wznieść ten monument ku czci Gorma, swojego ojca i ku czci Tyry, swojej matki" (w tłum. autora)]. Dalej w inskrypcji Harald sinozęby szczyci się przy tej okazji zdobyciem władzy nad całą Danią i Norwegią i nawróceniem na chrześcijaństwo Duńczyków. 


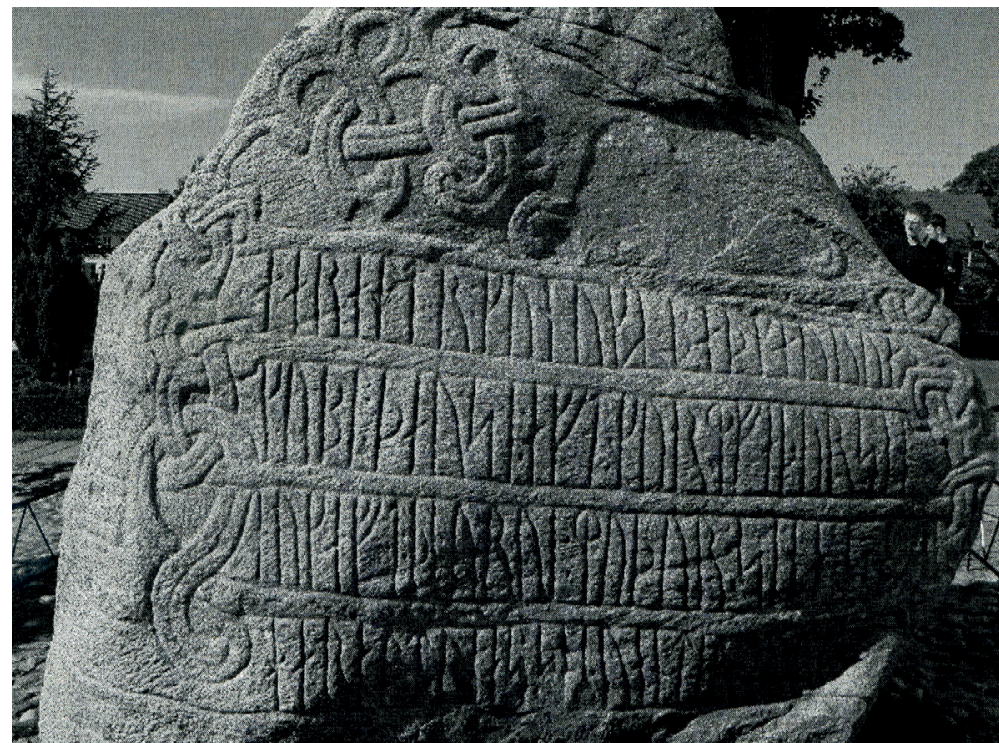

Ryc. 7. Jelling, kamień Haralda z inskrypcją ku czci Gorma i Tyry (https://rundata.info/ [dostęp: 16.07.2020])

Fig. 7. Jelling, Harald stone with an inscription in honor of Gorm and Tyra (https://rundata.info/https:// rundata.info/ [accessed on 16.07.2020])

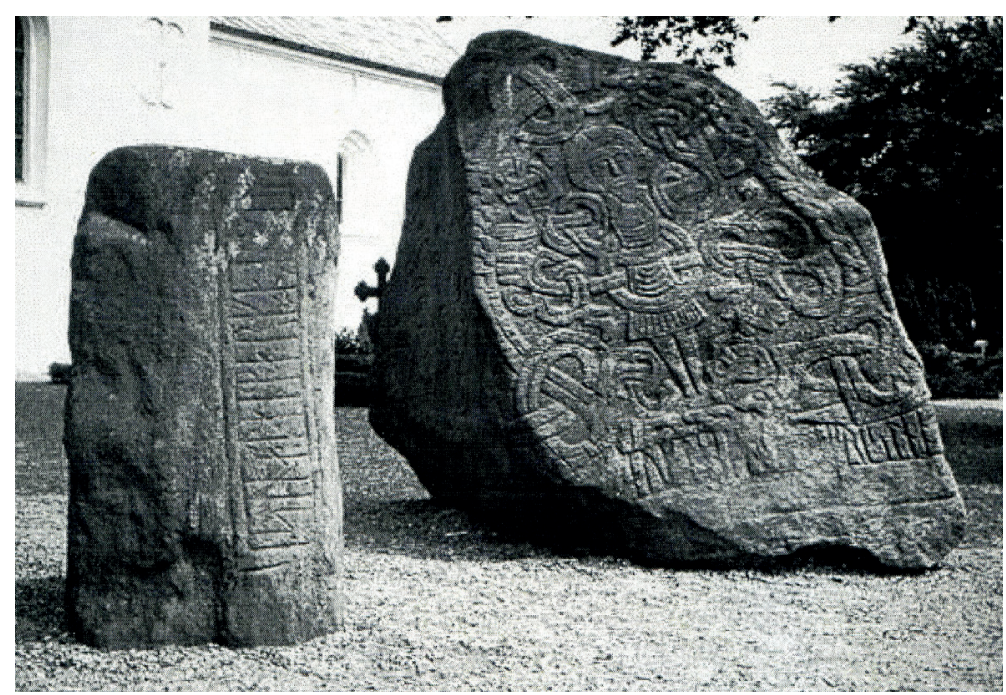

Ryc. 8. Jelling, kamień Haralda ze sceną ukrzyżowania i kamień Gorma ku czci jego żony Tyry (https:// rundata.info/ [dostęp: 16.07.2020])

Fig. 8 Jelling, the Harald stone with the crucifixion and the Gorm stone in honor of his wife, Tyra (https:// rundata.info/ [accessed on 16.07.2020]) 
Profesor Kazimierz Radwański, rozwijając badania nad Kopcem Krakusa, jako częścią dużego, królewskiego cmentarzyska kurhanowego na krakowskich Krzemionkach, odszukał oryginały austriackich planów odnotowujących kurhany (znałem tylko jeden z przedruku w pracy Rudolfa Jamki) i spróbował je bliżej zlokalizować w obecnym terenie, przede wszystkim jednak odnalazł kolejne ważne elementy topografii historycznej zajmującego nas tu miejsca (Radwański, 2000a, 2000b, 2002, 2003; Radwański, Tyniec, 2010). Na tym samym, już wspomnianym tu szwedzkim planie (por. ryc. 1 i 2), dostrzegł niezauważony przeze mnie ślad krakowskiej szubienicy, znanej w krakowskich dokumentach i stojącej w miejscu zwanym w związku z tym barwnie „Na Zboyu”, a tak naprawdę stojącej na którymś lub raczej obok

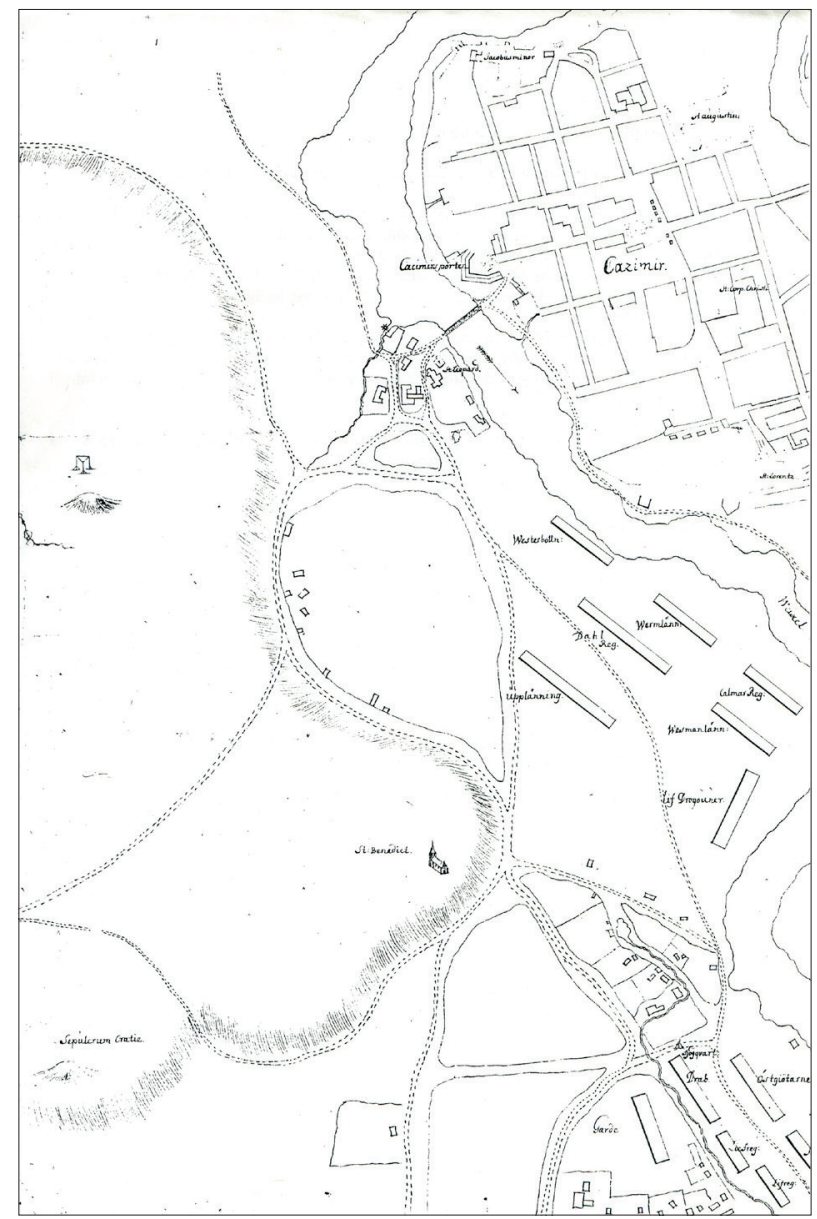

Ryc. 9. Krakowska szubienica stojąca „Na Zboyu” (fragment ze szkicu roboczego szwedzkiego planu Krakowa z 1702 roku [powiększenie]; por. też ryc. 2)

Fig. 9. Krakow standing gallows "Na Zboyu" (a fragment from a draft of the Swedish plan of Cracow from 1702 [enlarged]; see fig. 2) 
któregoś z owych dodatkowych i towarzyszących Krakusowi kopców (Radwański, 2000a, s. 269). Krakowską szubienicę widać już zresztą na szkicu Mateusza Meriana (patrz dalej: ryc. 12). Jak ustalił Radwański, to właśnie na niej powieszono, choć już chyba martwego, sławnego buntownika z czasów potopu szwedzkiego Kostkę Napierskiego, który twierdził, że był nieślubnym synem króla Władysława IV Wazy i którego za PRL-u przedstawiano w aureoli protokomunisty (jako przywódcę chłopskiego buntu podejrzewanego o konszachty z Chmielnickim). Bowiem Kraków miał tam właśnie swój typowy dla europejskich miast średniowiecznych Galgenberg. Co ciekawe, archeolodzy zauważyli częste wykorzystywanie w pełnym średniowieczu, ale także i dużo później starych kurhanów jako tego rodzaju miejsc egzekucji, przy czym zjawisko nie ogranicza się tylko do miast lokowanych na prawie niemieckim: przydrożna szubienica stanęła w średniowieczu (i to całkiem wcześnie) nawet na rozdrożu przy anglosaskich kurhanach w Sutton Hoo (Carver, 1998, s. 137-144).

Kazimierz Radwański wyprowadził też przekonująco w swoich studiach etymologię Rękawki, archaicznego ludowego święta ${ }^{6}$, celebrowanego pod Kopcem Krakusa we wtorek po Wielkanocy (ryc. 10), od zachowanego w czeskim i serbsko-chorwackim słowa rakev, oznaczającego trumnę i mogiłę (Radwański, 2002, s. 420), co nota bene stanowi ciekawy przyczynek do kwestii mocnych związków wczesnośredniowiecznej Małopolski ze słowiańskimi ziemiami na południe od Karpat.

Dzięki temu odkryciu stało się jasne, że było to pierwotne miano Kopca Krakusa, zapisane zresztą jako jego nazwa całkiem wyraźnie na dawnych rycinach, od siedemnastowiecznego sztychu Mateusza Meriana Młodszego poczynając. Nazwy tej już w czasach Długosza nie rozumiano, co doprowadziło do powstania opowieści objaśniającej ją drogą ludowej etymologii i powtarzanej przez wieki aż do dziś w Krakowie, mówiącej o spontanicznym usypaniu kopca po śmierci Kraka z ziemi przynoszonej w zawiązanych nogawkach i rękawach ${ }^{7}$. Jest to więc kopiec, który

${ }^{5}$ Ostatnio o egzekucji Napierskiego pisał Romuald Romański (Romański, 2012, s. 69).

${ }^{6}$ Było to i jest do dziś (obchodzi się je hucznie w Krakowie corocznie) święto o wyraźnych nawiązaniach do świąt wiosennych, takich jak wspomniane przez Długosza Stado (Potkański, 1924; Gieysztor, 2006, s. 196), mających także charakter pogańskich świąt zadusznych, z typowymi dla nich zabawami polegającymi na toczeniu i rzucaniu jaj, czyli przedmiotów-symboli odgrywających kluczową rolę w mitach kosmogonicznych jako symbol stworzenia świata, śmierci i powtórnych narodzin (i stąd nie przypadkiem powiązanych z chrześcijańską Wielkanocą i z powiązanymi z cyklem wielkanocnym Zielonymi Świątkami). W świecie słowiańskim wiosenne święto zmarłych, znane jako radunica, opisane zostało w późnym średniowieczu na Rusi, gdzie obchodzono je już w związku z chrześcijańskimi obrzędami wielkanocnymi; w jego rytuale pojawiają się oczywiście jaja, tak jak w przypadku krakowskiej rękawki. Jest to temat wart szerszego rozwinięcia! W Polsce radunica zostawiła ślady toponomastyczne (rzeka Radunia na Pomorzu i góra Radunia w masywie Ślęży). Późnośredniowieczne opisy radunicy zebrał V. J. Mansikka (Mansikka, 1922, s. 96-97, 258, 312).

7 Temat spontanicznego usypania kopca Krakusa i nazwy Rękawka (historyczno-folklorystycznej natury) ma bardzo obszerną literaturę; jej zręby zebrałem, pisząc o kopcu Wandy (Słupecki, 2005, s. 8889, przyp. 16), tam też i niektóre źródła od Miechowity przez Jana Kochanowskiego po Piotra Hiacynta Pruszcza i Aleksandra Obodzińskiego (nota bene znanego piewcy polskich wódek!). 


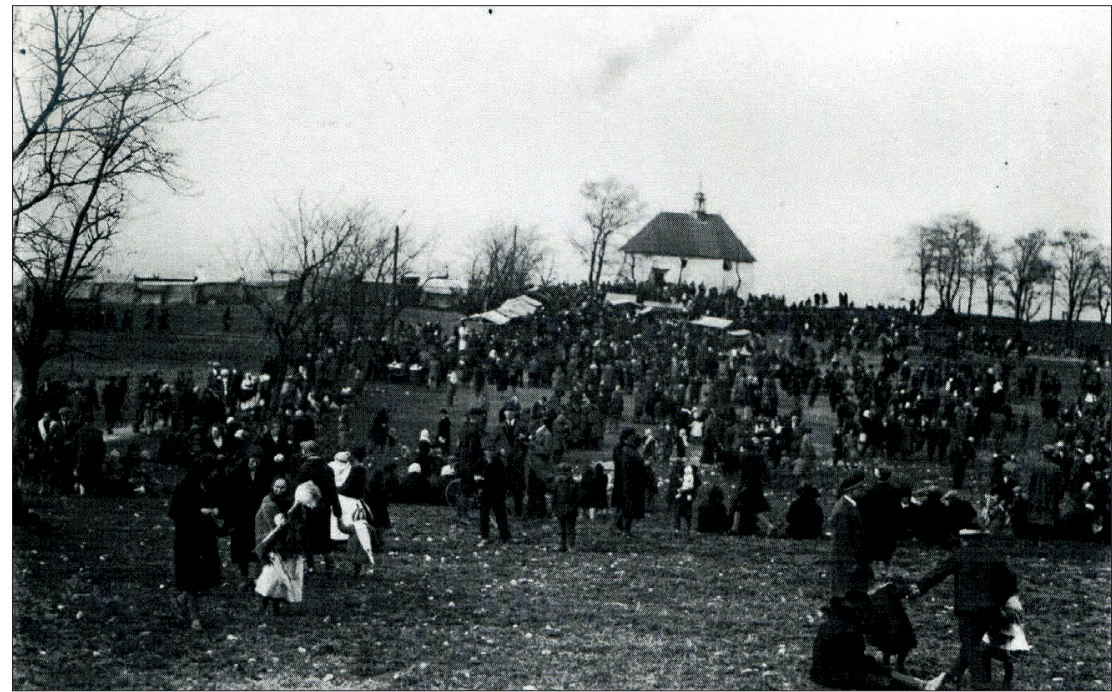

Ryc. 10. Obchody święta Rękawki obok kościółka św. Benedykta w 1926 roku (zdjęcie ze strony internetowej: https://cdn.glos24.pl/2020/04/rekawka-2016-1.jpg [dostęp 16.07.2020])

Fig. 10. The celebration of the Rękawka holiday next to the church of St. Benedict in 1926 (photo from the website: https://cdn.glos24.pl/2020/04/rekawka-2016-1.jpg [accessed on 16.07.2020])

pierwotnie nazywano dokładnie tak jak kopiec w Mogile - po prostu mogiłą ${ }^{8}$, tyle że używano do tego innego słowa (,rakiew”), o wyraźnie południowych nawiązaniach językowych. I co więcej, ta właśnie nazwa „rękawka” przetrwała do dziś jako miano ludowego święta o wielce archaicznym i w oczywisty sposób zadusznym charakterze, całkiem dobrze odpowiadającym słowiańskim obrzędom radunicy (patrz wyżej).

Dopiero gdy Mistrz Wincenty Kadłubek zapisał i na swój sposób zredagował krakowski mit początków i, stosownie do swoich potrzeb, legendarnego króla Kraka nazwał z łacińska Gracchusem, rakiew-Rękawkę można było uznać za grób Krakusa. Nienazwanego jednak po polsku, jak trzeba, Krakiem, ale za Mistrzem Wincentym właśnie Krakusem. Zwróćmy tu uwagę na łacińską formę i końcówkę tego słowa, co zawdzięczamy Kadłubkowi, który w swej opowieści, drapując Kraka w rzymską togę, przerobił mu imię na Gracchus (Słupecki, 2009)9 . Dlatego kopiec nazywany

${ }^{8}$ Dużo już dalej od Wawelu położony kopiec w Mogile, dominujący nad polami wsi nie przypadkiem tak właśnie nazwanej, znany jest nam dziś jako Kopiec Wandy. W 1222 roku biskup krakowski Iwo nadał cystersom wieś Mogila sive tumba" i tam też wnet powstał cysterski klasztor (źródła zebrałem w: Słupecki, 1998, s. 59). Dzięki temu wiemy, że pierwotna nazwa Kopca Wandy - to po prostu Mogiła (bez cienia jej związku z kimkolwiek), a powiązanie tej „mogiły” w Mogile z Wandą stało się możliwe dopiero od momentu, gdy autor Kroniki Wielkopolskiej zdecydował się utopić Wandę w Wiśle (patrz: Słupecki, 2005).

${ }^{9}$ W pracy Kadłubka nad zredagowaniem krakowskiej legendy pojawiają się zresztą różne warstwy i motywy, ze skandynawskimi (Słupecki, 1995) i czeskimi włącznie (patrz niżej). 
był w Krakowie od zawsze Kopcem Krakusa, a nie Kraka. Tyle że Kadłubek o pochowaniu Kraka w Kopcu Krakusa nic chyba jeszcze nie wiedział, a przynajmniej z taką swoją wiedzą się w Kronice nie zdradził. Choć warto tu zauważyć, że Mistrz Wincenty krakowską legendę początków nie tylko pouzupełniał i poprzerabiał, ale też zredagował w kilku punktach wyraźnie niespójnie. Wątek śmierci Kraka-Grakchusa bez jednego słowa o tym, gdzie go pochowano (Kadłubek Kopca Krakusa w ogóle nie wspomina!), jest na to jednym z kilku przykładów.

Po odkryciu innych dużych mogił zaznaczonych na krakowskich Krzemionkach na dawnych planach, mapach i szkicach stało się jasne, że obok Kopca Krakusa i niedaleko pobliskiego kościółka św. Benedykta rozpościerało się miejsce wyjątkowe w topografii przedpiastowskiego Krakowa i że było ono symbolicznie ważne dla całej krakowskiej wspólnoty. Była to zapewne królewska nekropola protopaństwa Wiślan, która musiała odgrywać szczególną rolę w organizacji przestrzeni społecznej Kotliny Krakowskiej z ulokowanym w jej centrum na Wawelu ośrodkiem władzy. Nad Wawelem, podobnie jak nad całą Kotliną Krakowską, dominował wtedy i mimo przesłaniającej go dziś współczesnej zabudowy wciąż dominuje dobrze zewsząd widoczny Kopiec Krakusa, wówczas jednak na Krzemionkach wznosiły się też inne wielkie mogiły i liczne małe kurhany; i można domniemywać, że grzebano w nich szczątki władców i służących im ludzi, zapewne dokonując najpierw spalenia zwłok - bo taki wówczas stosowano obrządek. Ich imion nie znamy, bo choć o „silnym wielce” księciu Wiślan wspomina Żywot Metodego (cap. 11, w: MPH, t. 1, 1864, s. 107), to nie bez powodu nie podaje jego imienia (Słupecki, 2019). Czy nazywał się on Krak - wykluczyć nie można, bardzo to jednak wątpliwe. Pewne tylko, że od imienia jakiegoś Kraka pochodzi nazwa Krakowa i że istniał mit o jakimś Kraku, w którym miejscowi widzieli legendarnego założyciela swojej wspólnoty tak jak Czesi, po praojcu Czechu-Bohemusie, za pierwszego swojego legendarnego przywódcę uważali Kroka, postać o imieniu nie przypadkiem podobnym, a tak naprawdę identycznym do naszego Kraka (Słupecki, 1993). Dopiero więc z tego mitu i z nazwy Krakowa stworzono legendarną postać Kraka, który pod piórem Kadłubka stał się Krakusem. A ówże Krakus, bynajmniej nie Krak, w swoim kopcu został pochowany dopiero w tekstach napisanych po Kadłubku. Kopiec Krakusa jako mogiłę Kraka wspomina jako pierwszy dopiero Jan z Dąbrówki w swoim Komentarzu do Kroniki Mistrza Wincentego ${ }^{10}$.

Jakby więc nie było, czy tak, czy może jednak inaczej, czy był w Kopcu Krakusa grób, czy też nie (żadnego czytelnego śladu pochówku w Kopcu Krakusa przecież nie odkryto, więc i inne interpretacje pierwotnej funkcji kopca, choćby militarne, wciąż są możliwe), a jeśli był to grób, to kto w nim został pochowany i jak miał na imię? było to bezspornie miejsce szczególne i ważne symbolicznie. Jeśli faktycznie pochowano w nim ważnego wiślańskiego władcę (a tak właśnie sądzę), to był to pochówek

${ }^{10}$ Ioannes de Dąbrówka, Commentum in Chronicam Polonorum Magistri Vincentii dicti Kadłubek, wyd. M. Zwiercan, A. Z. Kozłowska, M. Rzepiela, Kraków 2008 (MPH ns, t. 14), s. 32; por. Słupecki, 2015 . 
ciałopalny, którego śladów podczas prowadzonych tam w latach trzydziestych XX w. wykopalisk nie zauważono ${ }^{11}$. I nie miał on raczej na imię Krak, choć... tak całkiem to nawet $\mathrm{i}$ tego wykluczyć nie można.

Po zmianie wiary obok Kopca Krakusa bardzo wcześnie zbudowano na sąsiedniej kulminacji Góry Lasoty istniejący do dziś kościółek pod nieczęstym wezwaniem św. Benedykta, poświadczonym już w 1254 roku $^{12}$; początkowo była to, jak wykazały wykopaliska w latach sześćdziesiątych XX w., rotunda romańska lub nawet preromańska ${ }^{13}$, co tylko podkreśla wagę i znaczenie tego miejsca, które, jak widać, musiało zostać przez chrześcijaństwo koniecznie zawłaszczone. Po zbudowaniu przez Austriaków fortu, który zamknął dostęp do Kopca Krakusa, świętowanie Rękawki przeniosło się pod pobliski kościółek św. Benedykta, dzięki czemu głęboko średniowieczna tradycja święta do dziś dnia przetrwała.

Poświadczeniami w źródłach (kartograficznych, pisanych i ikonograficznych), symboliką i funkcją krakowskich kopców oraz ich porównaniem do podobnych obiektów skandynawskich zajmowałem się już wystarczająco obszernie w kilku dawniejszych, wspomnianych tu pracach. Pozostaje jednak pewien niebagatelny szczegół dobrze widoczny na dwóch z najważniejszejszych dawnych rycin przedstawiających Kopiec Krakusa (i gorzej widoczny, ale jednak, na kilku innych). I jest to szczegół wart porównania $\mathrm{z}$ tajemniczymi śladami widocznymi na przekroju kopca w publikowanej dokumentacji jego badań archeologicznych z lat trzydziestych XX w.

Zachęty i inspiracji dla podjęcia tego wątku badań dostarczył mi kościółek św. Mikołaja (Sv. Nikola) w chorwackim Ninie na dalmatyńskim wybrzeżu Adriatyku. Jest to pochodząca $\mathrm{z}$ samego początku dwunastego wieku (zbudowana około 1100 roku) maleńka rotunda - trikonchos o wymiarach 7,30 na 6,80 metrów, w XVI w. podczas inwazji tureckiej na Bałkany karnelizowana, to znaczy przebudowana u góry w obronną basztę w taki sposób, aby kościółek mógł pełnić również rolę strażnicy i pierwszego punktu oporu na drodze do położonego około kilometra dalej na północ portowego miasta $\mathrm{Nin}^{14}$. Otóż ta strategicznie położona rotunda wzniesiona została na wierzchołku pradziejowego kopca! Do jej budowy użyto zresztą obficie materiału i kamieniarki wziętych z ruin antycznego Ninu.

${ }^{11}$ Wcale nie tak sporadycznie wielkie kopce dostarczają badaczom poważnych zagadek; bywają wśród nich obiekty „puste”, zawierające bardzo enigmatyczne ślady pochówków, lub takie, w których pochówków po prostu nie widać!

${ }^{12}$ Patrz: Słupecki, 1998, s. 57-58 (tam źródła i literatura).

13 Patrz: Żurowska, 1988, s. 116 i 121; Świechowski, 2009, s. 236.

${ }_{14}$ Patrz: Goss, 1987, s. 52, 90-91, 158 i ryc. 77; Gvozdanović, 1969 (rotunda św. Mikołaja na okładce!). Rotunda św. Mikołaja na kopcu pod Ninem pojawiła się w polskiej literaturze naukowej w kontekście wspomnianych (na początku tego tekstu) badań prof. S. Tabaczyńskiego w Zawichoście (Rodzińska-Chorąży, 2018, s. 202). Przy okazji bałkańskich wątków badań warto odnotować kompetentnie wykorzystującą obszerną polską literaturę o Krakowie i Kopcu Krakusa pracę słoweńskiego archeologa Andreja Pleterskiego (Pleterski, 2014, s. 175-212). 


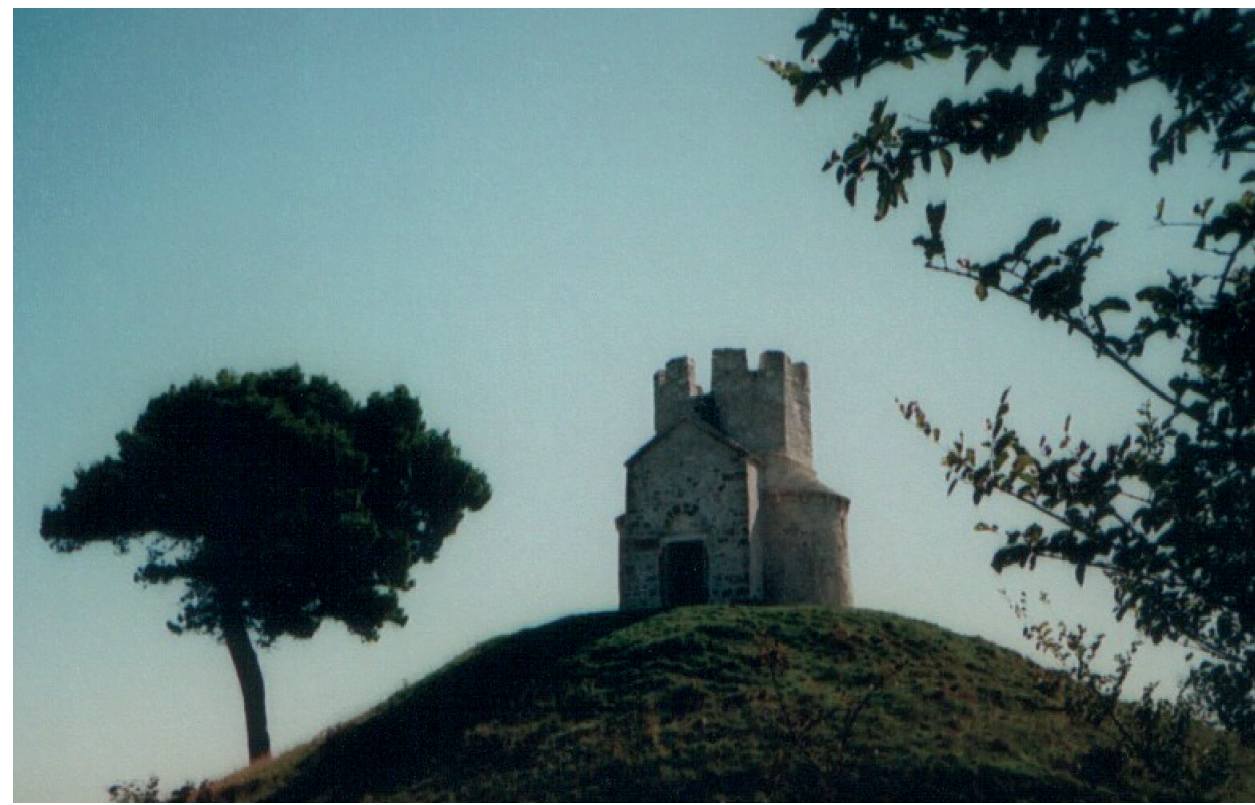

Ryc. 11. Kościółek - trikonchos św. Mikołaja na kopcu pod chorwackim miastem Nin (fot. L. P. Słupecki, 2007 rok)

Fig. 11. Church (rotunda - trikonchos) of St. Nicholas on a mound near the Croatian town of Nin (photo by L. P. Słupecki, 2007)

Wróćmy teraz pod Kraków, na Krzemionki. Na pochodzącej z XVII w. rycinie Mateusza Meriana przedstawiającej Kraków w 1617 roku i przedrukowanej w Civitates Orbis Terrarum Georga Brauna i Franza Hogenberga ${ }^{15}$ dobrze widać Kopiec Krakusa, a obok niego kościółek św. Benedykta. Kopiec jest na sztychu jasno opisany jako tumulus dictus rękawka.

$\mathrm{Na}$ wierzchołku kopca widnieje dziwna konstrukcja, na pierwszy rzut oka bardziej przypominająca rakietę Marsjan niż kościółek czy małą kapliczkę.

Kapliczki stojące na wierzchołkach kopców i kurhanów znamy z ziem polskich bardzo dobrze; także na Kopcu Wandy znajdowała się takowa i przetrwała do XIX w. (dziś zastąpił ją współczesny monument upamiętniający królową Wandę). W Kronice Joachima Bielskiego w wydaniu z 1597 roku widzimy Kopiec Wandy na rycinie przedstawiającej Wandę skaczącą na koniu z mostu do Wisły; kopiec jest na rycinie i już na królową czeka, a na jego szczycie widać kapliczkę. Tę kapliczkę na Kopcu Wandy wspomina Bartosz Paprocki w 1584 roku, a opisał ją już całkiem

15 Jako autor tej ryciny drukowanej w dziele Brauna i Hogenberga (Georg Braun, Franz Hogenberg, Civitates orbis terrarum, t. 6, s. 43b) pojawia się w literaturze Edigius van der Rye. Jest to jednak nieomal dokładnie ten sam szkic, jaki uznaje się za dzieło Matthäusa Meriana Młodszego; jego rycina z przedstawieniem Krakowa mogła krążyć w kilku nawet wersjach, jakiś egzemplarz (chyba nieco inny niż przedrukowany przez Jamkę) pojawił się niedawno na aukcji! 


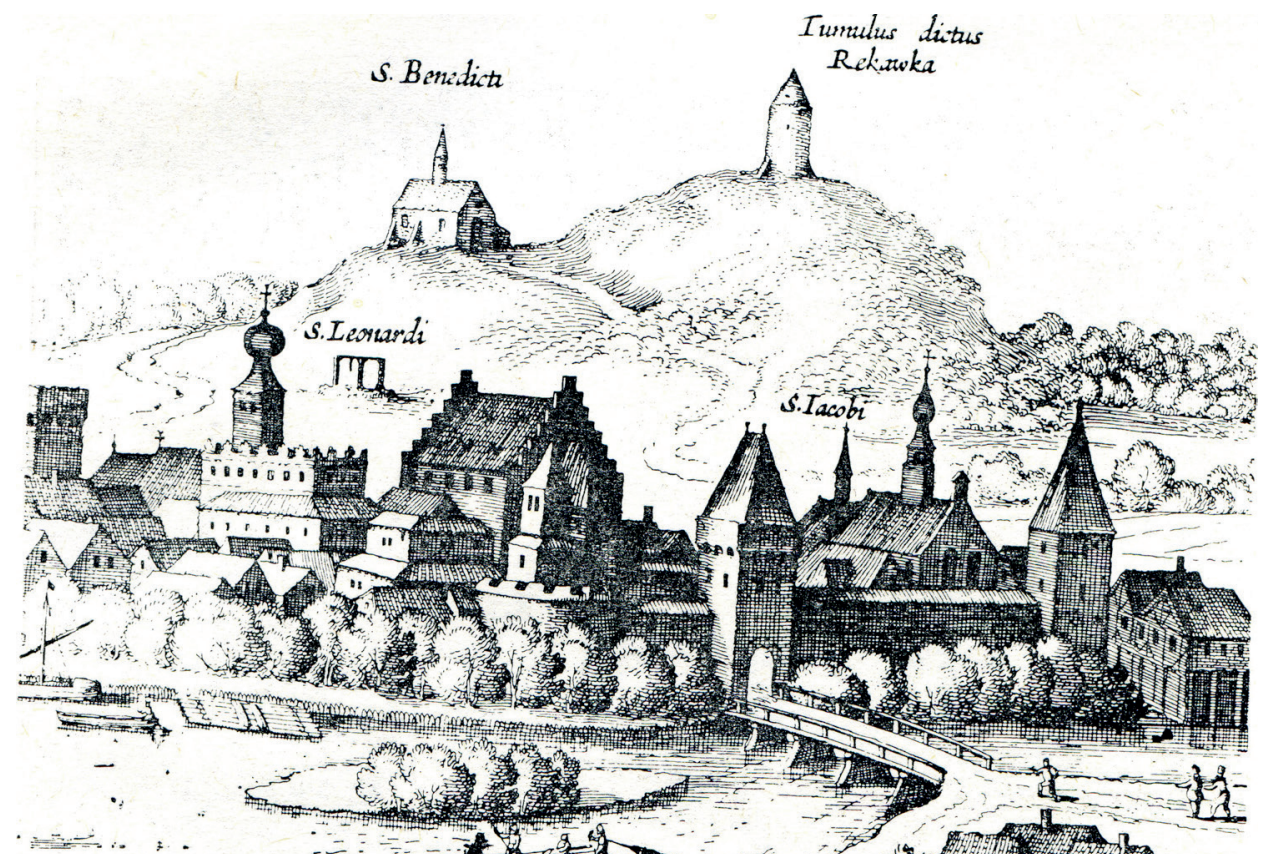

Ryc. 12. Fragment sztychu Mateusza Meriana z 1617 roku przedstawiającego panoramiczny widok na Kraków, wycinek z Kopcem Krakusa (za: Jamka, 1965, s. 187; por. też: https://www.atticus.pl/?pag=poz\&id=60013 [dostęp 16.07.20])

Fig. 12. Printmarking by Mateusz Merian from 1617, a fragment with the Krakus Mound (after: Jamka, 1965, p. 187, fig. 3; from the wwebsite: https://www.atticus.pl/?pag=poz\&id=60013 [accessed on 16.07.20])

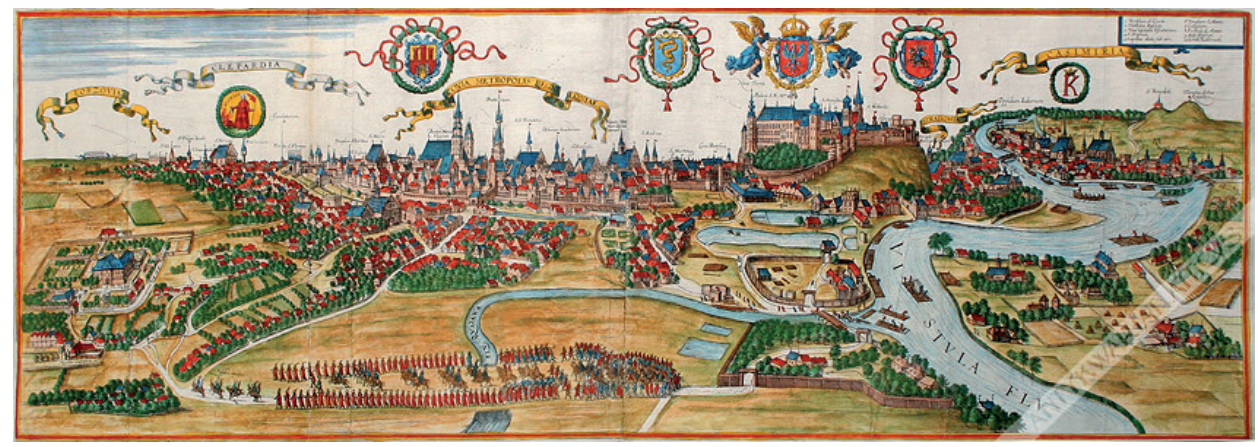

Ryc. 13. Widok Krakowa z lotu ptaka (Cracovia Metropolis Regni Poloniae, za: G. Braun, F. Hogenberg, Civitates Orbis Terrarum, t. 6, Cologne 1617, https://www.sanderusmaps.com/our-catalogue/antique-maps/europe/eastern-europe/old-antique-bird-s-eye-view-of-krakow-by-georg-braun-frans-hogenberg-17058 [dostęp 16.07.20])

Fig. 13. Aerial view of Cracow. A print by G. Braun and F. Hogenberg, Civitates Orbis Terrarum, vol. VI, Cologne 1617; https://www.sanderusmaps.com/our-catalogue/antique-maps/europe/eastern-europe/ old-antique-bird-s-eye-view-of-krakow-by-georg-braun-frans-hogenberg-17058 (accessed on 16.07.20) 
dokładnie w XVII w. Stanisław Sarnicki, przytaczając wyrytą na niej łacińską inskrypcję na cześć Wandy, jaka miała się tam znajdować ${ }^{16}$.

A co stało na Kopcu Krakusa? Na początku rosnąć miał na nim potężny dąb, którego korzenie odkryto podczas wykopalisk w latach trzydziestych. Zrobił on w polskiej archeologii sporą karierę, jako domniemane prapolskie święte drzewo, trafiając w rysunkowej wizji Kopca Krakusa na obwolutę czwartego, „wiślańskiego” tomu Początków Polski Henryka Łowmiańskiego.

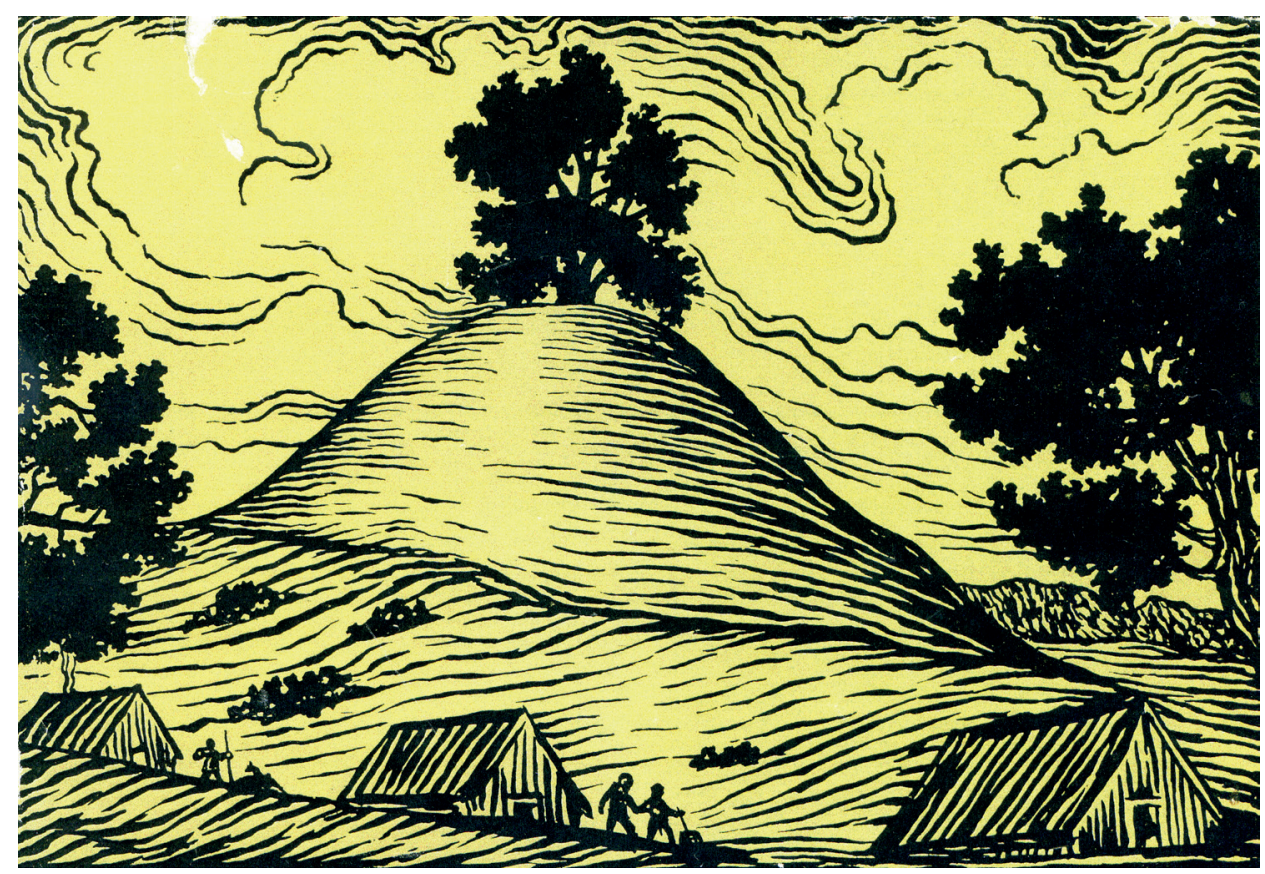

Ryc. 14. Rysunkowa wizja prastarego dębu rosnącego na kopcu Krakusa umieszczona na obwolucie do 4 tomu Początków Polski Henryka Łowmiańskiego, Warszawa 1970 (rys. Z. Górnicki)

Fig. 14. Ancient oak on the Krakus Mound. Dust jacket for volume IV of the Beginnings of Poland by H. Łowmiański (drawing by Z. Górnicki)

A co było potem? Miedzioryt Adolfa Lautensacka, pokazujący wojska arcyksięcia Maksymiliana oblegające Kraków w 1587 roku, przedstawia wprawdzie kopce Krakusa i Wandy w sposób bardzo schematyczny, ale na obu zaznacza krzyże, jednak raczej jako symbole jakichś obiektów sakralnych stojących na ich szczytach niż przedstawienia realnie odzwierciedlające rzeczywistość. Rycinę tę znał i wykorzystał już Rudolf Jamka (Jamka, 1965, s. 185).

16 Źródła i literaturę zebrałem w: Słupecki, 1998, s. 60. 


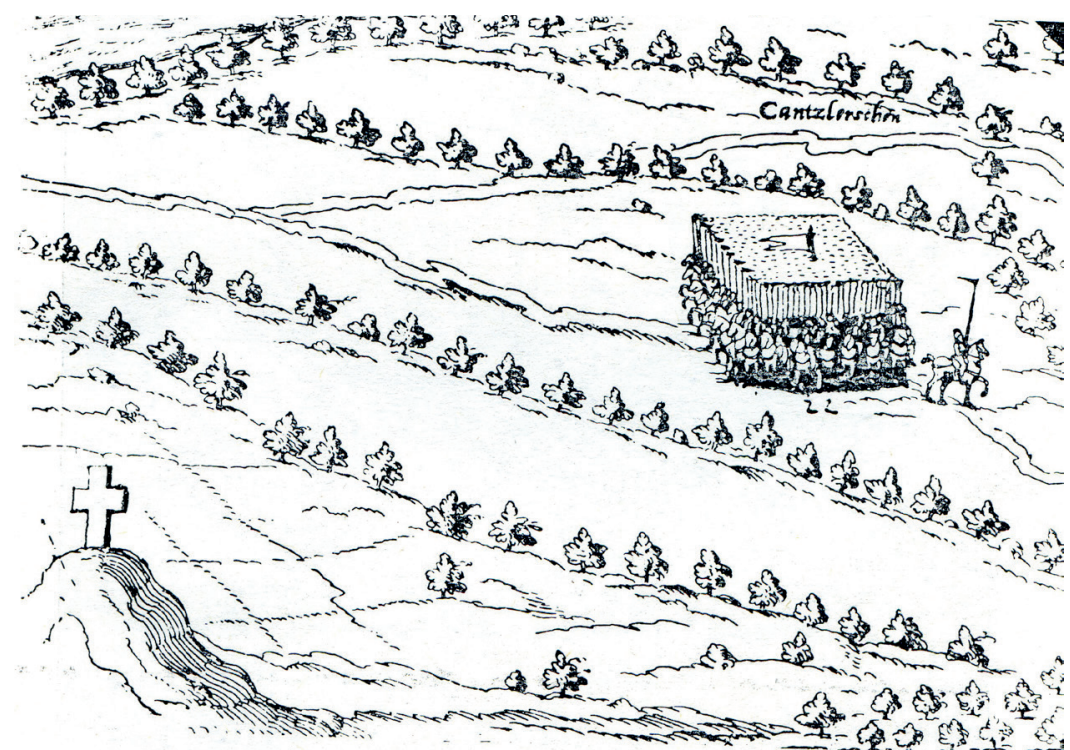

Ryc. 15. Miedzioryt Adolfa Lautensacka. Krzyż na Kopcu Krakusa w 1587 roku (za: Jamka, 1965, s. 185)

Fig. 15 Lautensacka copperplate engraving. Cross on the Krakus Mound in 1587 (after: Jamka, 1965, p. 185)

W 1591 roku Tomasz Treter zamieścił w Regnum Poloniae Icones portrety Kraka i Wandy, z widokiem na ich kopce w oknach pokazanych w tle ich postaci na rysunkach. Na obu kopcach widać jakieś budowle, jakby kapliczki (Słupecki, 1998, s. 58). Czyżby więc stała tam po prostu mała kapliczka?

Gdy jednak patrzymy na sztych Meriana, widzimy wyraźnie, że na Kopcu Krakusa stało coś potężniejszego niż zwykła kapliczka (por. ryc. 12). Co prawda obiekt ten na rycinie przedstawiony został dość schematycznie, ale nie możemy zapominać, że widzimy go w powiększeniu, a dokładność i finezja maleńkich szczegółów na marginesie wielkiego przedstawienia panoramy ogromnego miasta nie grały tu aż tak wielkiej roli dla artysty, którego dzieła nikt nie miał przecież oglądać pod lupą. Ważne było dla niego jednak, aby na kopcu obiekt ten się znalazł - skoro na nim stał i był dobrze widoczny - także z oddali. Widzimy wszakże nawet jakieś przypory przy murze, widzimy, że jest to chyba rotunda (choć jakby na rotundę zbyt wysoka), zaś z prawej strony, jak się zdaje, zasygnalizowano nawet fakturę kamiennego muru. A niewielka kropka pośrodku konstrukcji może markować istnienie małego, romańskiego okienka. Nie była to więc mała kapliczka, ale kaplica. Konkretnie rotunda, jakkolwiek nienaturalnie wysoka. A skoro na kopcu stała rotunda, to trochę inaczej trzeba też sobie wyobrażać wspominane w źródłach nowożytnych iluminacje Kopca Krakusa dokonywane przy okazji ważnych państwowych wydarzeń.

Gdy zaś spojrzymy na przekrój kopca w publikacji wykopalisk prowadzonych na kopcu Krakusa w latach trzydziestych, a opublikowanej przez Rudolfa Jamkę 
(Jamka, 1965), to możemy na jego szczycie dostrzec dwa głębokie, położone w odległości około 8 metrów od siebie zagłębienia wtórnie „wypełnione kredowym rumoszem z humusem". Zagłębienia chyba zbyt duże, aby mogły być to ślady po wkopach pod wieżę triangulacyjną, z którymi je powiązano. Mogły to być natomiast ślady po wybranych do szczętu fundamentach rotundy.

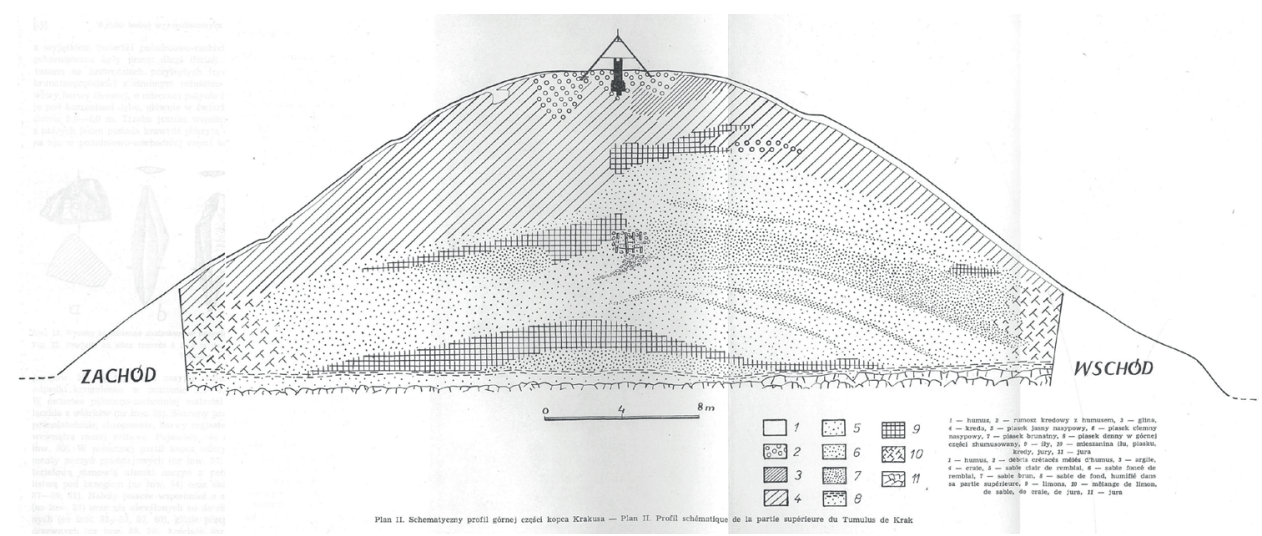

Ryc. 16. Przekrój przez Kopiec Krakusa - badania z lat trzydziestych XX w., opublikowane przez Rudolfa Jamkę (za: Jamka, 1965, s. 200, tabl. 2)

Fig. 16. Cross-section of the Krakus Mound; research from the 1930s published by R. Jamka (after: Jamka, 1965, p. 200, fig. 2)

Opierając się na przywołanym wyżej (ryc. 12) powiększeniu fragmentu rysunku Mateusza Meriana i używając jako argumentu pomocniczego śladów po domniemanych wkopach fundamentowych widocznych w dokumentacji wykopalisk prowadzonych na kopcu Krakusa, mając ponadto w pamięci jako analogię rotundę św. Mikołaja stojącą do dziś na prahistorycznym kopcu pod chorwackim Ninem (ryc. 11), stawiam tezę, że na szczycie Kopca Krakusa wzniesiono rotundę, zapewne przedromańską lub romańską. Wzniesiono ją po tym, gdy przestał już na nim rosnąć piękny, potężny dąb, którego korzenie dobrze są widoczne w dokumentacji wykopalisk poniżej śladu (ewentualnego) wkopu fundamentowego rotundy. Na miedziorycie Lautensacka istnienie domniemanej przeze mnie rotundy byłoby zaznaczone symbolicznie krzyżem, a jej obecność została mgliście uchwycona w oknie na portrecie Kraka u Tretera. Najlepszy jej wizerunek zawdzięczamy sztychowi Mateusza Meriana. Rotunda na Kopcu Krakusa istniała jednak jeszcze przynajmniej do chwili, gdy została uchwycona, i to całkiem dokładnie, przez Erica Joensona Dahlbergha na jego rycinie przedstawiającej Kraków podczas oblężenia miasta przez Szwedów w czasie Potopu jesienią 1655 roku $^{17}$. Choć przetrwała niewiele

17 Patrz: Słupecki, 1998, s. 58. Problem wymaga dalszej analizy ikonograficznej, a przede wszystkim dotarcia do dobrych reprodukcji lub oryginałów rycin Lautensacka, Tretera i Dahlbergha (niemożliwej do wykonania w czasach epidemii). 
dłużej, zresztą mimo że pokazana została i przez Meriana, i przez Dahlberga w wielkim uproszczeniu jako niewielki detal kompozycji ich panoram Krakowa, to nie sprawia wrażenia budowli znajdującej się już wówczas w stanie kwitnącym. Na szwedzkim planie z 1702 roku nie ma po niej nawet śladu.

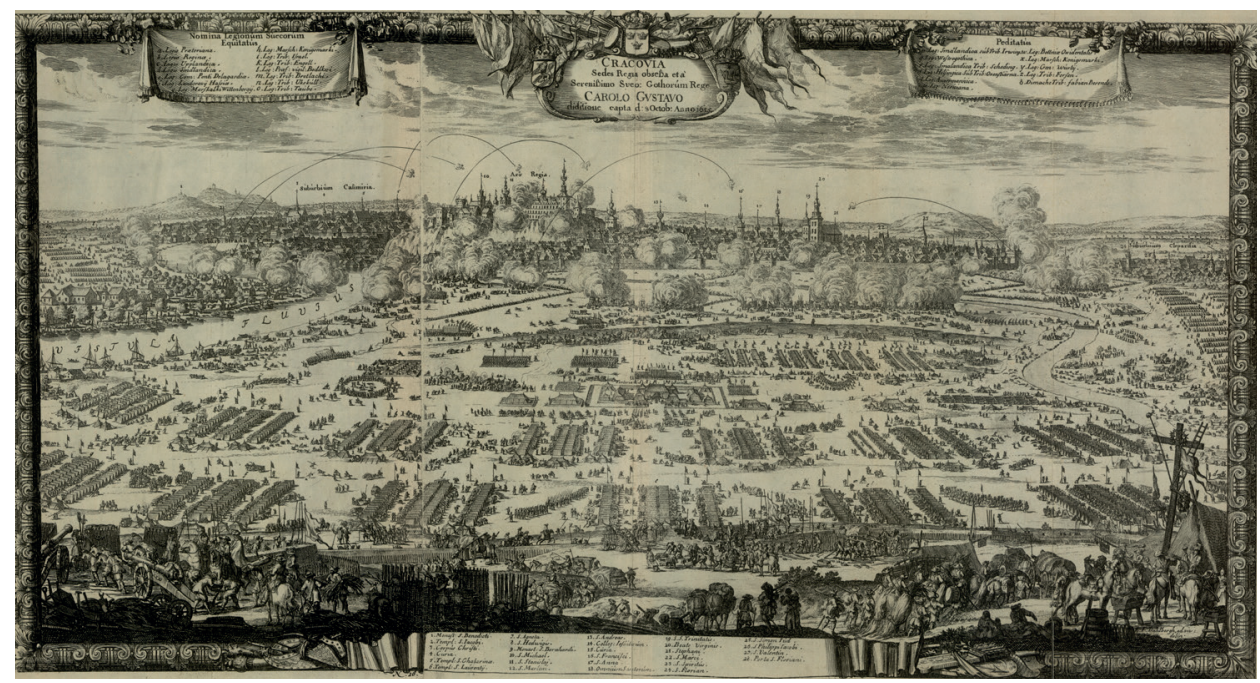

Ryc. 17. Oblężenie Krakowa jesienią 1655 roku. Fragment miedziorytu według rysunku Erika Joensona Dahlbergha. W: S. Pufendorf, De rebus a Carolo Gustavo Suecice gestis [...], Norimbergæ 1696 (za: Heyduk, 1971, s. 151, ryc. 56, https://polona.pl/item/cracovia-sedes-regia-obsessa-et-a-serenissimo-sveo-gothorum-rege-carolo gustavo,NDA2OTY3Mjg/0/\#info:metadata [dostęp 16.07.2020])

Fig. 17. The siege of Krakow in the fall of 1655. Fragment of a copperplate engraving after a drawing by Erik Joenson Dahlbergh. In: S. Pufendorf, De rebus a Carolo Gustavo Suecice gestis [...], Norimbergæ 1696 (after: Heyduk, 1971, p. 151, fig. 56, https:/polona.pl/item/cracovia-sedes-regia-obsessa-et-a-serenissimo-sveo-gothorum-rege-carolo-gustavo,NDA2OTY3Mjg/0/\#info:metadata [accessed on July 16, 2020])

Jeśli się nie mylę, to istnienie aż dwóch rotund - jednej (św. Benedykta) w pobliżu, a drugiej na samym szczycie Kopca Krakusa - jeszcze bardziej podkreślałoby postulowaną przez Kazimierza Radwańskiego ważną rolę Góry Lasoty z cmentarzyskiem na Krzemionkach w symbolicznej topografii Kotliny Krakowskiej. Rolę trwającą po dziś dzień. Gdyby bowiem nad Wawelem nie dominował Kopiec Krakusa, nie usypano by pewnie Kopca Kościuszki. A kto wie, czy inspiracji do usypania Krakusa (lub może wtedy jeszcze raczej - Rękawki) nie dostarczył we wczesnym średniowieczu pradziejowy zapewne Kopiec Wandy...

Ewentualne istnienie na Kopcu Krakusa romańskiej rotundy nie jest bynajmniej ostatnią zagadką, jaką poruszony tu przeze mnie temat stawia do rozwiązania. Wróćmy na bliską Profesorowi Tabaczyńskiemu Wielkopolskę i zauważmy, jak odmiennie wygląda problem wielkich, monumentalnych mogił i cmentarzysk w Małopolsce 
i w Wielkopolsce. Pod Krakowem z pewną dozą prawdopodobieństwa dostrzegamy wokół Kopca Krakusa pogańską nekropolę tamtejszej dynastii. A gdzie są monumentalne, pogańskie mogiły ojca i dziada Mieszka Pierwszego? Jeśli były i jeśli odważymy się ich szukać, to kierowałbym wzrok w okolice Mogilna (nie przypadkiem tak nazwanego), gdzie także nie przypadkiem zbudowany został jeden $\mathrm{z}$ dwóch najstarszych klasztorów benedyktyńskich w Polsce. Ten drugi, małopolski, powstał w Tyńcu pod Krakowem, całkiem niedaleko od cmentarzyska na Krzemionkach i po tej samej stronie Wisły. Ale dlaczego ten pierwszy, wielkopolski, powstał pod Mogilnem, a nie pod Gnieznem czy Poznaniem?

\section{BIBLIOGRAFIA}

Carver, $\mathrm{M}$.

1998 Sutton Hoo. Burial ground of Kings? Frome - London: British Museum Press.

Duczko, W. (red.)

1993 Arkeologi och miljögeologi i Gamla Uppsala. Studier och rapporter. Occasional Papers In Archaeology (OPIA), t. 7. Uppsala: Societas Archaeologica Uppsaliensis.

1996 Arkeologi och miljögeologi i Gamla Uppsala. Studier och rapporter. Occasional Papers In Archaeology (OPIA), t. 11. Uppsala: Societas Archaeologica Uppsaliensis.

Gieysztor, A.

2006 Mitologia Slowian. Warszawa: Wydawnictwo UW.

Bukowski, W., Dybaś, B., Noga, Z. (red.)

2012 Galicja na józefińskiej mapie topograficznej 1779-1783, t. 1, cz. A i B (Faksymilia arkuszy 1-30). Kraków: Polska Akademia Nauk, Uniwersytet Pedagogiczny w Krakowie.

Goss, V.

1987 Early Croatian Architecture. A Study of the Pre-Romanesque. London: Duckworth.

Gvozdanović, V.

1969 Starohrvatska arhitekture. Zagreb: DAH.

Heyduk, B.

1971 Dahlbergh w Polsce. Dziennik i ryciny szwedzkie z dziejów „Potopu” 1656-1657. Wrocław - Warszawa - Kraków - Gdańsk: Ossolineum.

Ioannes de Dąbrówka

2008 Commentum in Chronicam Polonorum Magistri Vincentii dicti Kadtubek. Wstępem i przypisami opatrzył Marian Zwiercan przy współpracy Anny Zofii Kozłowskiej i Michała Rzepieli (Monumenta Poloniae Historica, nova series, 14).

Jamka, R.

1965 Wyniki badań wykopaliskowych na Kopcu Krakusa w Krakowie. Slavia Antiqua, 12, 183-234.

Lindeberg, $\mathrm{P}$.

1591 Commentarii Rerum Memorabilium in Europa Ab Anno Octuagesimo sexto, usque ad praesentem nonagesimum primum gestarum (etc.). Hamburgii: Wolfius; https://www.europeana.eu/pl/item/9200332/ABO__BZ175107803 [dostęp: 16.07.2020].

Łowmiański, H.

1970 Początki Polski. Z dziejów Stowian w I tysiącleciu n.e., t. 4. Warszawa: Państwowe Wydawnictwa Naukowe. 
Mansikka, V. J.

1922 Die Religion der Ostslaven, t 1: Quellen (Folklore Fellows Communications, t. 43). Helsinki: Suomalainen Tiedeakatemia.

Bielowski, A.

1864 Monumenta Poloniae Historica, t. 1. Lwów: Zakład Narodowy im. Ossolińskich.

Pleterski, A.

2014 Kulturni genom. Prostor in njegovi ideogrami môtične zgodbe. Studia mythologica Slavi$c a$, Supplementa, suppl. 10. Lubljana: Založba ZRC.

Potkański, K.

1924 Wiadomości Długosza o polskiej mitologii. W: K. Potkański (red.), Pisma pośmiertne, t. 2 (s. 3-93). Kraków: Polska Akademia Umiejętności.

Radwański, K.

2000a Kopiec Krakusa składnikiem wielkiego cmentarzyska kurhanowego na krakowskich Krzemionkach. W: J. Rydzewski (red.), 150 lat Muzeum Archeologicznego w Krakowie (s. 267-280). Kraków: Oficyna Cracovia.

2000b Kraków głównym ośrodkiem organizacji protopaństwowej Wiślan. W: A. Buko, P. Urbańczyk (red.), Archeologia w teorii i praktyce (s. 535-555). Warszawa: NOW Scientia.

2002 Nekropola grobów kurhanowych na Krzemionkach wraz z monumentalnym Kopcem Krakusa - głównym ośrodkiem ceremonialnym krakowskiego centrum władzy w IX-X w. W: C. Buśko (red.), Civitas et villa. Miasto $i$ wieś w średniowiecznej Europie środkowej (s. 417-428). Wrocław: Instytut Archeologii i Etnologii Polskiej Akademii Nauk.

2003 Wielkie kopce krakowskie i próba uściślenia ich chronologii. Rocznik Krakowski, 19, 5-23. Radwański, K., Tyniec, A.

2010 Cracow in Archaeological Research. W: A. Buko, M. McCarthy (red.), Making a Medieval Town. Patterns of Early Medieval Urbanisation (s. 175-185). Warszawa: Instytut Archeologii i Etnologii Polskiej Akademii Nauk.

Rodzińska-Chorąży, T.

2018 Tetrakonchos w Zawichoście. W: S. Tabaczyński, D. Wyczółkowski, D. Cyngot (red.), Zawichost we wczesnym średniowieczu (s. 180-207) (Origines Polonorum t. 12). Warszawa: Instytut Archeologii i Etnologii Polskiej Akademii Nauk.

Romański, R.

2012 Najstynniejsze bękarty w dziejach Polski. Losy pozamatżeńskich dzieci królów i książat polskich. Warszawa: Wydawnictwo Bellona.

Słupecki, L. P.

1993 Wawel jako święta góra a słowiańskie mity o zajęciu kraju. Przegląd Religioznawczy, 2(168), 3-18.

1995 Vanda mari, Vanda terrae, aeri Vanda imperet. The Cracovian tripartite earth-heaven-sea formula with its Old Icelandic, Old Irish and Old-High-German counterparts. Światowit, 40, 158-167.

1998 Monumentalne kopce Krakusa i Wandy pod Krakowem. W: A. Buko (red.), Studia z dziejów cywilizacji. Studia ofiarowane profesorowi Jerzemu Gassowskiemu w pięćdziesiąta rocznice pracy naukowej (s. 57-71). Warszawa: Instytut Archeologii Uniwersytetu Warszawskiego.

1999 The Krakus and Vanda's Burial Mounds of Cracow. Studia Mythologica Slavica, 2, 77-98.

2002 Die Grossgrabhügel von Krak und Wanda in Krakau - zwei Königsgräber des 8.-10. Jahrhunderts in Kleinpolen im Licht kartographisher, schriftlicher und archäologischer Quellen. W: G. Helmig, B. Scholkmann, M. Untermann (red.), Centre, Region, Periphery. Medieval Europe. 3rd International Conference of Medieval and Later Archaeology (Preprinted Papers, t. 2) (s. 394-399). Basel: Folio-Verlag Dr. G. Wesselkamp. 
2004 Large burial mounds of Cracow, Poland (8th-10th Century AD). An Example of Ideas-Exchange between Slavs and Scandinavians. W: G. Guðmundsson (red.), Current Issues in Nordic Archeology. Proceedings of the 21st Conference of Nordic Archaeologists (s. 135-140). Akureyri - Reykjavík: Society of Icelandic Archaeologists.

2005 Wanda leży w naszej ziemi co nie chciała Niemca? Problem czasu powstania i symbolicznego znaczenia Kopca Wandy w Mogile pod Krakowem. W: A. Pieniądz-Skrzypczak, J. Pysiak (red.), Sacrum. Obraz i funkcja w społeczeństwie średniowiecznym (s. 83-98). Warszawa: Wydawnictwa Uniwersytetu Warszawskiego.

2006 Large Burial Mounds of Cracow. W: L. Šmejda (red.), Archaeology of Burial Mounds (s. 119-142). Plzeň: University of West Bohemia, Department of Archaeology.

2009 Krak i Wanda przed Kadłubkiem, u Kadłubka i po Kadłubku. W: A. Dąbrówka, W. Wojtowicz (red.), Onus Athlanteum. Studia nad kronika biskupa Wincentego (Studia Staropolskie sn, t. 25) (s. 160-189). Warszawa: Instytut Badań Literackich Polskiej Akademii Nauk.

2015 Jan z Dąbrówki - polskie dzieje bajeczne i uzupełnienie mitu krakowskiego o kopce Kraka i Wandy. W: A. Dąbrówka, M. Olszewski (red.), Komentarz Jana z Dąbrówki do Kroniki biskupa Wincentego (Studia Staropolskie sn, t. 42) (s. 252-259). Warszawa: Instytut Badań Literackich Polskiej Akademii Nauk.

2019 Damnatio memoriae. Chrzest wiślańskiego władcy i jego apostazja, czyli dlaczego tak mało wiemy o cyrylo-metodejskim chrześcijaństwie u Wiślan. W: J. Sperka (red.), Silesia - Polonia - Europa. Studia historyczne dedykowane Profesorowi Idziemu Panicowi (s. 1-5). Katowice - Bielsko-Biała: Polskie Towarzystwo Historyczne, Ministerstwo Nauki i Szkolnictwa Wyższego.

Sturluson, S.

1939 Heimskringla, Ynglinga saga. Íslenzk Fórnrit, t. 26 (wyd. Bjarni Aðalbjarnarson). Reykjavík: Hið islenzka fornritafélag.

Świechowski, Z.

2009 Katalog architektury romańskiej w Polsce. Warszawa: DiG.

Tabaczyński, S., Wyczółkowski, D., Cyngot, D. (red.)

2018 Zawichost we wczesnym średniowieczu (Origines Polonorum, t. 12). Warszawa: Instytut Archeologii i Etnologii Polskiej Akademii Nauk.

Żurowska, K.

1988 Architektura monumentalna u progu chrześcijaństwa w Polsce. Nasza Przeszłość, 69, $115-131$.

Archiwalia

Cracovia Sedes Regia obsessa et a Serenissimo Sveo [et] Gothorum Rege Carolo Gustavo deditione capta die 8 Octobris 1655, Norymbergae 1696 (https://polona.pl/item/cracovia-sedes-regia-obsessa-et-a-serenissimo-sveo-gothorum-rege-carolo-gustavo,NDA2OTY3Mjg/0/\#info:metadata [dostęp 21.07.2020])

Geometrisches Plan vom Schloß Wawel - Geometrisches Plan vom Schloß Wawel und die Stadt bei dem: Cracauv. Krigsarkivet: Sveriges krig 10: 182a (mapa) i 182b (szkic), Stockholm 1702.

\section{ROTUNDA ON THE KRAKUS MOUND?}

\section{Sum mary}

The Krakus burial mound dominating over the City of Cracow is only the last relic of a great barrows cemetery being allegedly a burial ground of the dynasty ruling the Polish local proto-state of Vistulanians in the time about 9th century AD - as it was demonstrated in some of author's and 
Kazimierz Radwański's papers. As a medieval tradition the Krakus Mound was connected to the King Krak, the legendary ruler and founder father of that state. The over mentioned papers cast light on some problems connected to this Mound (including its legend, history, name, excavations and links to the local myth of origins), and on the importance of the burial mound cemetery around. Its former existence was however recorded on old maps and drawings only and for centuries it fell into oblivion. The present paper focuses on the next enigma of the Mound, which is the presence of a mysterious building on the top which appears on some engravings of the late 16th and 17th century, but especially well was presented only twice as detail of Matthäus Merian (1617) and Eric Dahlberg (1655) panoramas of the city of Cracow. On the Swedish map from 1702 the top of the mound is already empty. The hypothesis is that it was probably a small Romanesque rotunda. Such structure to established over a big burial mound resembles the case of St. Nicholas (Sv. Nikola) church in Nin (Croatia) which is an early Romanesque rotunda (triconchos) from ca. 1100 AD which stands till today on the top of a prehistoric mound located by the town of Nin. It seems that during excavation of the Krakus mound in 30ties a negative of a destroyed and dig out foundations of the rotunda were registered which remained uninterpreted, at least in that way. 